\title{
THE EUROPEAN UNION AND THE BREXIT DILEMMA - A VERY BRITISH PROBLEM?
}

\author{
ANNEGRET ENGEL*
}

\begin{abstract}
This paper discusses the key legal issues arising from the constitutional conceptions of both the $E U$ and the UK in the latter's withdrawal process. It argues that the adherent Brexit dilemma is mainly the result of the UK's non-codified constitution on the one hand, exposing legal uncertainty over institutional procedures, regional involvement, or the precise status of international law. Nevertheless, the EU's composition of the withdrawal process as defined in Article $50 \mathrm{TEU}$ has also caused confusion during the negotiations of the withdrawal agreement, the future EU-UK relationship, as well as the possibility of revocation. Due to its unprecedented nature, the several uncertainties and flaws inherent in this case bave consumed valuable time and resources which could have otherwise been used more efficiently in order to ensure a smooth and orderly departure from the EU.
\end{abstract}

\section{INTRODUCTION}

The European Union (EU) traces its origins back to the European Coal and Steel Community (ECSC) which was established by the Treaty of Paris in 1952. Numerous states have since become members of this exclusive 'club' by accession, the procedure of which can now be found in Article 49 TEU. It was not until 2009 however, when the current Treaty of Lisbon entered into force, when the legal framework explicitly allowed for the withdrawal of an existing Member State. Essentially, withdrawal is the reverse of accession, ie the unwinding of membership status. The procedure to do so is laid out in Article 50 TEU, a provision - by the face of it - clearly defined, seemingly leaving no doubt as to the rights and obligations during the withdrawal process for the withdrawing Member State as well as the various institutions of the EU and the remaining Member States.

Reality has, however, painted a different picture when the United Kingdom of Great Britain and Northern Ireland (UK) in June 2016 by means of a referendum voted to leave the EU and subsequently triggered Article 50 TEU in March 2017. The so far unprecedented withdrawal has been a rather painful exercise for both sides of endless negotiations and re-negotiations, legal court proceedings, and turf wars of competence in multilevel governance. The departure of the previously 'awkward' partner' has since developed into a full-blown dilemma threatening the integrity of the EU which, almost three years after the UK's decision to leave, is still far from being over. But what are the very roots of the problem? How did we end up in this mess? And could it have been

\footnotetext{
* Senior Lecturer for EU law at Lund University, Sweden. I have until recently worked at Cardiff University $(\mathrm{UK})$ and the Wales Governance Centre and I was engaged in various exchanges with the Welsh Government, which has informed my current research on Brexit. Email Annegret.Engel@jur.lu.se. The usual disclaimer applies.

${ }^{1}$ Stephen George, An Awkward Partner: Britain in the European Community (3rd edn, OUP 1998).
} 
avoided or would it have been different had a Member State other than the UK decided to withdraw from the EU?

This article will be arguing that the legal problems deriving from the inherited constitutional conceptions of both the EU and the UK have led to the current Brexit dilemma. On the one hand, the UK's perspective is one of the more peculiar ones as compared to most other Member States. The lack of a written constitution, devolution, and a dual approach to international law have created various obstacles along the way to leave the EU. In addition, international obligations will continue to pose restrictions on the UK's approach post-Brexit irrespective of its membership in the EU. On the other hand, from the EU's perspective, fundamental principles have complicated the quest for possible solutions and alternatives to the reoccurring impasse in the negotiations of the withdrawal agreement as well as the future relationship between the EU and the UK. In addition, Article 50 TEU itself does not answer all questions regarding the options of a Member State during the withdrawal process, in particular the possibility to be revoked, which therefore had to be clarified by the European courts. These issues shall be addressed in the following.

\section{UK PERSPECTIVE}

According to Article 50(1) TEU, the withdrawing Member State must do so according to its own constitutional requirements. That includes all questions of institutional and regional involvement from the beginning of the decision finding process until the end of negotiations resulting in the final departure. In addition, account must be had of any overriding international obligations which remain unaffected by the withdrawal from the EU. This all sounds very logical and straightforward, however in reality - and in the rather peculiar case of the UK which, unlike most other countries, does not have a written constitution - this has proven to be somehow more challenging than one would have expected at first sight.

The referendum itself which led to the decision to withdraw from the EU, although it can be and has been criticised for various reasons (binary choice of answer options, ${ }^{2}$ nonbinding legal character, ${ }^{3}$ overspending of the leave campaign, ${ }^{4}$ to name but a few) shall not be discussed here as these are political decisions, the way the referendum was held and the fact that the UK government felt bound by its result. What this section will be discussing instead are the legal consequences of an un-codified constitution in such an unprecedented and extraordinary case of withdrawal from the EU. One may think, as stated above, that if

\footnotetext{
2 The official question on the ballot paper was: 'Should the United Kingdom remain a member of the European Union or leave the European Union?', see UK Government website: https://www.gov.uk/government/topical-events/eu-referendum/about\#what-will-the-referendum-questionbe.

${ }^{3}$ The 'advisory' nature of referenda in the UK indicates that their result does not necessarily have to be followed by the government, in particular if there is only a small majority as it was the case in the 2016 referendum (Leave $51.9 \%$ versus 48.1\% Remain, see https://www.electoralcommission.org.uk/findinformation-by-subject/elections-and-referendums/past-elections-and-referendums/eureferendum/electorate-and-count-information).

${ }^{4}$ See the official report of The Electoral Commission on an investigation of the Leave campaign for breaking electoral law: http://www.electoralcommission.org.uk/ data/assets/pdf file/0019/244900/Report-of-aninvestigation-in-respect-of-Vote-Leave-Limited-Mr-Darren-Grimes-BeLeave-and-Veterans-for-Britain.pdf.
} 
withdrawal is the reverse of accession it should be rather straightforward and powers could simply be repatriated to the institutions and regions previously in charge (ie before the UK has become an EU member). However, as the following will show, the disentanglement of competences is a complex matter indeed and in particular if there is a lack of legal guidance which poses real challenges to the constitutional system.

\subsection{THE ROYAL PREROGATIVE VERSUS PARLIAMENTARY SOVEREIGNTY}

The UK's Brexit dilemma started at the first hurdle: triggering Article 50 TEU and the question as to which UK-internal constitutional requirements are necessary to do so. Does it fall under the royal prerogative? Or does Parliament have a say in this? Unlike many of its European neighbours, where such issues would be addressed in their written constitutions, the UK's situation was rather unclear. ${ }^{5}$ Unsurprisingly, these issues were raised in judicial proceedings in the Miller case and were only clarified in its final judgment by the UK Supreme Court in January $2017 .^{6}$

One of the most peculiar features of (mostly) common law systems is the Crown's or royal prerogative. ${ }^{7}$ Under UK law this means that the government, acting on behalf of the monarch, may take action without consent of the UK Parliament. However, the exact scope of this prerogative power is unclear due to the lack of a written constitution, although the courts have previously provided some guidance. For example, the royal prerogative may be exercised for matters in foreign affairs, including the signing as well as the termination of international treaties. ${ }^{8}$ Along this line and with regard to the UK's withdrawal from the EU treaties, the Secretary of State for Exiting the European Union tried to argue in favour of the Crown's prerogative in this case. However, as was previously established, the royal prerogative 'does not extend to altering the law or conferring rights upon individuals or depriving individuals of rights which they enjoy in domestic law without the intervention of Parliament."

As a country taking a dualist approach to international law, the UK clearly distinguishes between foreign and domestic law, with an act of Parliament necessary for the former to take effect in the national legal system. While EU laws would thus initially be considered foreign law, the European Communities Act (ECA) 1972 has 'domesticated' EU rights and obligations to become effective as part of the UK legal framework. ${ }^{10}$ Indeed, after more than four decades of EU membership, the disentanglement of laws by source (UK or EU) would be rather difficult. The defenders of the royal prerogative in the Miller

\footnotetext{
${ }^{5}$ See also Michael Gordon (2016) 'Brexit: a challenge for the UK constitution, of the UK constitution?' EuConst 12(3), 409-444.

${ }^{6} \mathrm{R}$ (Miller) v Secretary of State for Exiting the European Union [2017] UKSC 5. See eg discussion in Juha Raitio and Helena Raulus (2017) 'The UK EU referendum and the move towards Brexit' MJ 24(1), 25-42.

${ }^{7}$ See eg discussion in Thomas Poole (2010) 'United Kingdom: The royal prerogative' IJCL 8(1), 146-155.

${ }^{8}$ Lord Templeman in JH Rayner (Mincing Lane) Ltd v Department of Trade and Industry [1990] 2 AC 418, p 476.

9 Lord Oliver of Aylmerton in JH Rayner (Mincing Lane) Ltd v Department of Trade and Industry [1990] 2 AC 418, p 500.

10 The inherent conflict caused under this dualist approach is best illustrated with the Factortame cases and the application of the principle of EU supremacy under UK law, Case C-213/89, The Queen v Secretary of State for Transport, ex parte: Factortame Ltd and others, EU:C:1990:257.
} 
case however argued that despite this domestication of EU laws via the medium of the ECA, it nevertheless remained foreign by nature as was evident in the possibility to withdraw from EU membership and therefore to cease to apply EU laws. This reasoning was rejected by the Supreme Court which found that:

the continued existence of the new source of law created by the 1972 Act, and the continued existence of the rights and other legal incidents which flow therefrom, cannot as a matter of UK law have depended on the fact that to date ministers have refrained from having recourse to the Royal prerogative to eliminate that source and those rights and other incidents. ${ }^{11}$

Ultimately, the Supreme Court concluded, withdrawal from the EU and therefore repeal of the ECA 1972 can only be exercised by the UK Parliament enacting primary legislation, thus upholding the principle of parliamentary sovereignty: ${ }^{12}$ 'ministers require the authority of primary legislation' as mandate in order to be able to make use of their prerogative powers to trigger Article $50 \mathrm{TEU}$, rather than the other way around. ${ }^{13}$ Earlier, the House of Lords Constitutional Committee had already expressed its concerns of constitutionality in case Parliament would not be consulted before triggering Article 50 TEU:

It would be constitutionally inappropriate, not to mention setting a disturbing precedent, for the Executive to act on an advisory referendum without explicit parliamentary approval - particularly one with such significant long-term consequences. ${ }^{14}$

Thus confirming the prevalence of the principle of parliamentary sovereignty over the royal prerogative for cases of domesticated foreign laws, the Supreme Court's judgment is nevertheless evidence of the conflict - and even uncertainties - inherited in the constitutional framework of the UK. ${ }^{15}$ In addition, the quest for the correct institutional procedure has taken valuable time and resources before being able to trigger Article 50 TEU. Only after this judgment was the UK able to proceed with the necessary legislation which, after its approval by Parliament, ${ }^{16}$ gave the government the required mandate and thus paved the way for the withdrawal process to officially commence. ${ }^{17}$

\footnotetext{
${ }^{11}$ R (Miller) v Secretary of State for Exiting the European Union [2017] UKSC 5, para 93.

12 Jeffrey Goldsworthy, The Sovereignty of Parliament: History and Philosophy (Clarendon Press 1999).

${ }^{13}$ R (Miller) v Secretary of State for Exiting the European Union [2017] UKSC 5, para 101.

${ }^{14}$ House of Lords Select Committee on the Constitution (2016) 'The invoking of Article 50 on the

Constitution', $4^{\text {th }}$ Report of Sessions 2016-1, p 8.

15 See also Sionaidh Douglas-Scott (2016) 'Brexit, Article 50 and the Contested British Constitution' MLR

79(6), 1019-1040.

16 The House of Commons voted in favour by 498 to 114.

${ }_{17}$ The UK Parliament's decision to trigger Art 50 TEU was subsequently complemented with the European Union (Withdrawal) Bill 2017, Bill to Repeal the European Communities Act 1972 and make other provision in connection with the withdrawal of the United Kingdom from the EU.
} 
Another conflict which has occupied the judiciary as well as the legislature in the UK has been that of the different devolved administrations and their powers. ${ }^{18}$ According to the UK's devolution settlements, certain competences have been decentralised and transferred to the devolved regions of Scotland, ${ }^{19}$ Wales, ${ }^{20}$ and Northern Ireland. ${ }^{21}$ Areas for which competences have been devolved under these settlements include, but are not limited to, health, education, agriculture, and the environment. ${ }^{22}$ However, according to the Sewel Convention, the devolution of competences is merely an expression of goodwill which means that the UK Government retains the ultima ratio to legislate in any area of law, even those of devolved powers if deemed necessary. ${ }^{23}$ As a result, the distribution of competences within the UK is non-binding and cooperative in nature and thus could be challenged on a case-by-case basis.

Unsurprisingly, this issue was indeed raised in the Miller case with the devolved administrations claiming their veto power in the initiation of Brexit proceedings. Essentially, they argued that the UK Parliament would need their consent in order to being able to withdraw from the EU, since devolved competences would also be affected. However, the Supreme Court ruled that no such veto power could be derived from the Sewel Convention for the devolved administrations for triggering Article 50 TEU and thus dismissed their claims. ${ }^{24}$ It highlighted the political nature of the convention for which it did not consider the judiciary being the ultimate arbiter, but rather the choice of the UK Government. More, recently the latter has required the legislative consent from the devolved administrations in relation to the EU Withdrawal $\mathrm{Act}^{25}$ as well as the Trade Bill. ${ }^{26}$ Whilst being denied a veto on Brexit itself, influence over how competences are being repatriated to the UK after Brexit is equally vital to the devolved regions. In particular, those areas of devolved competences are under threat of being centralised in the interest of greater unity on the UK internal market post-Brexit.

During the UK's EU membership, the principle of subsidiarity according to Article 5 TEU allowed for regional representation of interests at European level for non-exclusive EU competences. ${ }^{27}$ Under such policy areas, the devolved regions have been able to individually shape policy-making for their territories and to directly receive EU subsidies. With the repatriation of powers from Brussels to Westminster rather than directly to the

\footnotetext{
18 See also Jo Hunt 'Devolution' in Michael Dougan (ed.), The UK after Brexit: Legal and Policy Challenges (Insentia 2017), 35-52.

19 Scotland Act 1998.

${ }^{20}$ Government of Wales Acts 1998 and 2006.

${ }^{21}$ Northern Ireland Act 1998.

22 This also varies as not all devolved regions have the same type and extent of competences.

${ }^{23}$ Memorandum of Understanding and Supplementary Agreements between the UK Government, Scottish Ministers, the Cabinet of the National Assembly for Wales and the Northern Ireland Executive Committee (December 2001) (Sewel Convention).

${ }^{24} \mathrm{R}$ (Miller) v Secretary of State for Exiting the European Union [2017] UKSC 5, para 150.

${ }^{25}$ European Union (Withdrawal) Act 2018, see progress: https://services.parliament.uk/bills/201719/europeanunionwithdrawal.html.

26 Trade Bill 2017-19, see progress: https://services.parliament.uk/bills/2017-19/trade.html.

${ }_{27}$ See $e g$ Rudolf Hrbek (2003) 'The role of the regions in the EU and the principle of subsidiarity' The International Spectator 38(2), 59-73; Antonio Estella de Noriega, The EU Principle of Subsidiarity and its Critique, (OUP 2002).
} 
devolved administrations, it remains questionable whether the UK Government will be willing to redistribute such competences to the different regions ${ }^{28}$ In addition, according to Schedule 2 of the EU Withdrawal Bill, ${ }^{29}$ the devolved administrations have rather limited powers in relation to retained EU laws: particularly problematic is the fact that according to paragraph 2(1) '[n]o regulations may be made (...) unless every provision of them is within the devolved competence of the devolved authority.' Essentially, this paves the way for a UK-internal competence creep as competences are often overlapping, touching on various policy areas at the same time, and can hardly ever be considered in isolation.

As could thus be argued, the UK-internal struggles are a direct consequence of the vagueness and non-binding nature of the distribution of competences between the devolved regions. The only devolved region with some leverage in the Brexit negotiations is Northern Ireland due to the ten DUP MPs needed to keep the current minority government in place. However, this does not change the legal uncertainties surrounding devolution itself and the move towards more centralised powers post-Brexit which is being justified by the need to avoid further fragmentation of the UK internal market in order to attract international trading partners and foreign investment once the UK has terminated its membership in the EU.

\subsection{INTERNATIONAL OBLIGATIONS}

EU and international laws are closely intertwined and their disentanglement, far away from being easy, may continue to pose certain restrictions on the UK post-Brexit. In particular, concerning policy areas with a transnational or even global scope, such as external trade or the environment, international obligations will continue to bind the UK in the post-Brexit era irrespective of its membership in the EU. This holds true not only for the often mentioned WTO rules, ${ }^{30}$ but also other international treaties of which the UK has become an independent signatory alongside the EU during its membership. In fact, this practice establishes a bilateral relationship vis-à-vis the third country thus capable of holding the UK accountable regardless of EU membership. ${ }^{31}$ As goes without saying, the UK will be able to unilaterally withdraw from such treaties after Brexit if it wishes to renegotiate its individual conditions or completely change its international strategy. ${ }^{32}$ However, this might result in an increased isolation on the world stage - even if only temporarily. It also remains questionable whether the UK would be able to renegotiate better conditions after its departure from the EU as an independent country due to the various internal political and legal uncertainties.

\footnotetext{
${ }^{28}$ See eg discussion in relation to environmental law in Annegret Engel and Ludivine Petetin (2018) 'International obligations and devolved powers - ploughing through competences and GM crops' Environmental Law Review 20(1), 16-31.

${ }^{29}$ European Union (Withdrawal) Bill 2017, Bill to Repeal the European Communities Act 1972 and make other provision in connection with the withdrawal of the United Kingdom from the EU.

30 eg compliance with the 1994 General Agreement on Tariffs and Trade (GATT).

${ }^{31}$ See eg Marise Cremona (2006) 'External Relations of the EU and the Member States: Competence, Mixed Agreements, International Responsibility, and Effects of International Law' EUI Law Working Paper No. $2006 / 22$.

32 As is eg happening with the 1964 London Fisheries Convention, see Mure Dickie (2017) 'UK begins to row back from fisheries convention’ Financial Times, https://www.ft.com/content/12451e48-5db5-11e7-9bc8$\underline{8055 f 264 a a 8 b .}$
} 
In addition, the UK's ability to divert from the much contested EU standards may be further limited by the so-called 'Brussels effect'. ${ }^{33}$ This describes the practice by which international trading partners tend to align their standards and even legislation with those of the EU in order to facilitate trade. Also called the concept of extraterritoriality, ${ }^{34}$ this is further evidence of the EU's influence and market power worldwide. ${ }^{35}$ Thus for the UK, this could potentially mean problems with existing trading partners if its post-Brexit strategy is to significantly lower its standards, for example technical or environmental, so as to attract certain other trading partners not usually compliant with the EU's high standards, such as China or the U.S. ${ }^{36}$ Ultimately, this could lead to a 'race to the bottom' which would have severe ramifications for the UK's ability to engage in trade on a global scale. Rather, the UK's future approach should reflect a careful consideration of the margins available for sensitive alignment for a successful trading strategy to be put in place.

\section{EU PERSPECITVE}

The EU's position has been very clear from the beginning and consistent throughout the negotiations: legally as codified in the treaties as well as politically. Nevertheless, the UK's withdrawal process has exposed several flaws deriving from the setting of Article 50 TEU itself. As stated above, withdrawal can be viewed as the reverse of accession, which certainly holds true from a procedural aspect. However, there is a significant legal difference: During the process of a potential Member State acceding, that state is legally still outside of the EU until accession is complete, thus it constitutes an external issue. In contrast, an existing Member State wanting to leave legally remains a member until withdrawal is complete and consequently constitutes an internal issue. Therefore, as could be argued, a significant share of the Brexit dilemma stems from the inherent legal concept of Article 50 TEU since internal issues by default receive more prominence and ultimately have the potential to create more turmoil from inside than external issues.

\subsection{NEGOTIATING THE WITHDRAWAL AGREEMENT}

Article 50(3) TEU envisages a two-year withdrawal period at most from the moment of notification after which 'the Treaties shall cease to apply to the State in question'. The insertion of such a time restriction - unlike in Article 49 TEU for accession - certainly has to be welcomed in that it is aimed to avoid departing Member States remaining inside the EU for an extended amount of time. However, this only applies once the European Council has been notified according to Article 50(2) TEU. As can be seen with the case of the UK, it took whole nine months after the referendum before notification to withdraw was officially issued and Article 50 TEU was triggered. ${ }^{37}$ In addition, even once the twoyear period has started, it can still be extended according to Article 50(3) TEU by

\footnotetext{
33 Anu Bradford (2012) 'The Brussels Effect' Northwestern University Law Review 107(1), 1-67.

${ }^{34}$ In relation to financial regulation, see Joanne Scott (2014) 'The new EU 'extraterritoriality" CMLR 51(5), 1343-1380.

35 See also Anu Bradford (2014) 'Exporting Standards: The Externalization of the EU's Regulatory Power Via Markets' International Review of Law and Economics 42, 158-173.

${ }^{36}$ See $e g$ the failed TTIP Agreement between the EU and the U.S.

${ }^{37}$ UK Referendum to leave: 23 ${ }^{\text {rd }}$ June 2016; Notification to withdraw: $29^{\text {th }}$ March 2017.
} 
unanimity. ${ }^{38}$ Despite this high threshold for extension and the resulting veto power for each remaining Member State, there is no restriction on how long this extension can be or how many times an extension can be granted, which in fact renders it indefinite. As could be argued, the possibility - even if only theoretical - to prolong the withdrawal period indefinitely is rather problematic in terms of legal certainty. ${ }^{39}$

According to Article 50(2) TEU 'the Union shall negotiate and conclude an agreement' with the withdrawing Member State, 'setting out the arrangements for its withdrawal, taking account of the framework for its future relationship with the Union.' This withdrawal agreement is to be negotiated and concluded during the two-year period after notification according to Article 218(3) TFEU, requiring consent of the European Parliament and qualified majority voting in the Council. In contrast, the actual agreement regulating the future relationship between the EU and the then ex-Member State will formally start to be negotiated after departure. ${ }^{40}$ The former is thus an EU-internal agreement, whereas the latter is an EU-external matter, ie an international agreement. ${ }^{41}$ This distinction is crucial as the future relationship can only be established once it is clear on which terms and conditions the departed Member State has in fact left the EU. As has been pointed out by Tridimas (2016), the withdrawal agreement 'may provide for the treatment of existing rights and obligations but cannot create any new rights'. ${ }^{42}$ The three main aspects thus covered by the withdrawal agreement between the EU and the UK were citizens' rights, border issues, and the financial settlement. ${ }^{43}$

During the time of the negotiations of the withdrawal agreement the exiting Member State legally remains a full member of the EU with all rights and duties such membership entails until actual withdrawal is complete and the EU treaties cease to apply. ${ }^{44}$ What is in legal terms a clear-cut provision faces difficulties in political realities due to a potential conflict of interests: a Member State wishing to leave the 'club' is still obliged to uphold the EU's fundamental principles and to participate in EU institutions and the various meetings at European level. As can be seen in the case of the UK, problems are likely to arise if the withdrawing Member State is forced to hold elections for the European Parliament shortly before exit or simply poses a threat as to blocking important decisions at EU level, such as

\footnotetext{
38 This is not to be confused with the transition period, as agreed between the EU and the UK, which concerns the time after withdrawal and thus already concerns an external matter. A detailed discussion on this can be found in Michael Dougan (2018) 'An Airbag for the Crash Test Dummies? EU-UK Negotiations for a post-Withdrawal 'Status Quo’ Transitional Regime under Article 50 TEU’ CMLR 55(2/3), 57-99.

39 As can be seen with the UK's multiple requests for extension for short periods of time and the EU's unwillingness to refuse such requests, thus causing legal difficulties for the European Parliament elections and legal uncertainty for businesses and citizens.

${ }^{40}$ This fact has been subject to some public debate in the UK with some politicians suggesting the UK should insist on negotiating the future relationship alongside the withdrawal arrangements, see eg Boris Johnson https://www.politico.eu/article/boris-johnson-eu-legally-bound-to-discuss-trade-relationship/. 41 This will be discussed in the next section.

42 Takis Tridimas (2016) 'Article 50: An Endgame without an End?' King’s Law Journal 27(3), 297-313, p 309.

43 Agreement on the withdrawal of the United Kingdom of Great Britain and Northern Ireland from the European Union and the European Atomic Energy Community, as endorsed by leaders at a special meeting of the European Council on 25 November 2018,

https://assets.publishing.service.gov.uk/government/uploads/system/uploads/attachment data/file/75901 9/25 November Agreement on the withdrawal of the United Kingdom of Great Britain and Northe rn Ireland from the European Union and the European Atomic Energy Community.pdf.

44 Art 50(3) TEU.
} 
the budget. ${ }^{45}$ To this effect, the Council issued another reminder of the code of conduct when it granted a second extension on Article 50 TEU on 10 April 2019, stressing that this extension 'cannot be allowed to undermine the regular functioning of the Union and its institutions. ${ }^{46}$ In particular, the Council highlighted that automatic withdrawal would be inevitable if the UK were to refuse to hold elections for the European Parliament. The Council further reminded the UK that it was obliged

to act in a constructive and responsible manner throughout the extension in accordance with the duty of sincere cooperation and [expected] to fulfil this commitment and Treaty obligation in a manner that reflects its situation as a withdrawing Member State. To this effect, the United Kingdom shall facilitate the achievement of the Union's tasks and refrain from any measure which could jeopardise the attainment of the Union's objectives, in particular when participating in the decision-making processes of the Union. ${ }^{47}$

As goes without saying, this duty of participation does not include matters concerning the exiting Member State's own withdrawal; any such meetings are reserved for the remaining Member States despite the former's lingering membership. ${ }^{48}$

\subsection{THE FUTURE RELATIONSHIP}

Once the Member State in question has ended its membership and has left the EU, negotiations for an agreement on the future relationship may formally commence, after having merely been 'taken account of' in the withdrawal agreement according to Article 50(2) TEU. ${ }^{49}$ As such, this agreement on the future relationship constitutes an international agreement between the EU and a third country as provided for in Article 216 TFEU and in accordance with the procedure under Article 218 TFEU. According to Article 3(2) TFEU, the Union's competence to conclude international agreements is exclusive if, for example, its conclusion is 'necessary to enable the Union to exercise its internal competence, or in so far as its conclusion may affect common rules or alter their scope.' However, joint action of the Member States may still be required if a multitude of policy areas and thus different types of competences $^{50}$ are covered by the envisaged international agreement

\footnotetext{
${ }^{45}$ See eg comments made by Conservative MP Jacob Rees-Mogg before a new extension pledge was made by the UK, https://www.politico.eu/article/rees-mogg-uk-should-play-hardball-on-eu-budget-if-brexitdelayed/.

${ }^{46}$ European Council Conclusion EUCO XT 20015/19, Special meeting of the European Council (Art. 50) (10 April 2019), https://www.consilium.europa.eu/media/39042/10-euco-art50-conclusions-en.pdf, point 3. 47 ibid, point 7.

48 This again might cause frustration within the exiting Member State and a feeling of not really being able to 'take back control' as was intended.

49 A non-binding political declaration on the envisaged future relationship was already negotiated alongside the negotiations of the withdrawal agreement: Political Declaration setting out the framework for the future relationship between the European Union and the United Kingdom, https://assets.publishing.service.gov.uk/government/uploads/system/uploads/attachment data/file/75902 $1 / 25$ November Political Declaration setting out the framework for the future relationship between $t$ he European Union and the United Kingdom .pdf.

${ }^{50} \mathrm{On}$ an extensive discussion of the different types of competences and the potential conflicts arising therefrom, see Annegret Engel, The Choice of Legal Basis for Acts of the European Union: Competence Overlaps, Institutional Preferences, and Legal Basis Litigation (Springer 2018).
} 
For example, in its Opinion 2/15 in relation to the free trade agreement between the EU and Singapore (EUSFTA), ${ }^{51}$ the court found that while several parts of the agreement would fall within the area of common commercial policy, including various social and environmental aspects of it, and thus be covered by the exclusive competence of the EU under Article 3(1)(e) TFEU, this could not be said of the entirety of the agreement. In particular, certain provisions regulating the protection of non-direct foreign investment and investor-State dispute settlement were considered to fall under the EU's shared rather than exclusive competences. ${ }^{52}$ Therefore, since the provisions of the agreement were of a mixed nature, the EUSFTA as a whole had to be concluded jointly between the EU and the Member States.

Essentially, such a joint approach gives each Member State, and even regions within the Member States, ${ }^{53}$ a veto over the negotiated agreement. The ratification process of mixed agreements may thus encounter difficulties which can be best illustrated with another international trade agreement between the EU and Canada (CETA). ${ }^{54}$ Here, the regional parliament of Wallonia in Belgium initially refused to give its consent for various reasons, one of which was Wallonia's concerns over the proposed Investment Court System, thus threatening to jeopardise years of complex trade negotiations and the successful conclusion of its final agreement. Wallonia only accepted the provisional entering into force of CETA under the condition that Belgium would request an opinion of the European courts on the validity of the contested Investment Court System. ${ }^{55}$ Despite the court's recently delivered opinion in favour of such a system and its compatibility under EU law, ${ }^{56}$ the agreement still requires ratification in all Member States to finally fully enter into force, which is thus not yet a given certainty. ${ }^{57}$

As can be seen from the above, a complex free trade agreement on the future relationship between the EU and the UK not only faces lengthy negotiations but also obstacles during the ratification process in the form of opposition from the Member States and their regions trying to protect their own interests in specific policy areas, for example agriculture, the environment, or the protection of certain technical standards. ${ }^{58}$ Possible alternatives in the event of a failed ratification of such an international agreement as put forward by Van der Loo and Wessel (2017) include the 'unsigning' or opt-outs for those Member States opposed to the agreement as well as the option of declarations. ${ }^{59}$ Another possibility was offered by Advocate General Sharpston who suggested in her opinion on the EUSFTA case a splitting of such multi-competence mixed agreements in order to ensure a swift ratification of those parts of the agreement which are covered by the EU's

\footnotetext{
${ }^{51}$ EU:C:2017:376. See also case comment by Marise Cremona (2018) 'Shaping EU Trade Policy post-Lisbon: opinion 2/15 of 16 May 2017', EuConst 14(1), 231-259.

52 Opinion 2/15, EUSFTA, EU:C:2017:376, para 305.

53 Depending on each Member State's constitutional requirements.

${ }^{54}$ Comprehensive Economic and Trade Agreement.

55 Opinion 1/17, Request for an opinion submitted by the Kingdom of Belgium pursuant to Article 218(11) TFEU (C 369/2).

${ }^{56}$ Opinion 1/17, Opinion pursuant to Article 218(11) TFEU (CETA), EU:C:2019:341.

${ }^{57}$ Cf. also the failed TTIP agreement between the EU and the U.S.

58 See eg Panos Koutrakos (2016) 'Negotiating international trade treaties after Brexit' E.L.Rev. 41(4), 475 478.

${ }^{59}$ Guillaume Van der Loo and Ramses A. Wessel (2017) 'The non-ratification of mixed agreements: Legal consequences and solutions' CMLR 54(3), 735-770.
} 
exclusive competences $^{60}$ and a better targeted political debate at intergovernmental level for the remaining policy areas without jeopardising the entirety of the negotiated deal. ${ }^{61}$

As could be argued, the inherited fragmentation within the EU deriving from an intergovernmental approach is particularly visible at international level and may have detrimental effects for such crucial negotiations in external relations, which has led various commentators to plead for greater unity in this area. ${ }^{62}$ However, there is a variety of factors determining the success and effectiveness of international negotiations, out of which speaking with a single voice is but one. ${ }^{63}$ The EU's international identity and trading power is also determined by the upholding of 'European values' and certain high standards, for which it is essential to allowing all actors and interest groups having their say in the negotiating/ratification process of such complex trade agreements. In addition, the most recently concluded Economic Partnership Agreement with Japan ${ }^{64}$ as well as the on-going negotiations for an EU-China Investment Agreement, ${ }^{65}$ are further evidence of the EU's ability to attract trading partners around the globe despite potentially lengthy and strenuous negotiations.

\subsection{REVOCABILITY OF ARTICLE 50 TEU}

Article 50 TEU remains silent as to the possibility to be revoked once it is triggered; ${ }^{66}$ a question which was raised in the Wightman case, ${ }^{67}$ where a preliminary ruling was brought before the European Court of Justice (ECJ) from the Court of Sessions (Scotland). Essentially, the court was asked to provide some clarity on the possibility of unilateral revocability of Article 50 TEU after a Member State's notification to withdraw but before actual departure, ie anytime within the two-year period prescribed in Article 50 TEU:

Where, in accordance with Article 50 [TEU], a Member State has notified the European Council of its intention to withdraw from the European Union, does EU law permit that notice to be revoked unilaterally by the notifying Member State; and, if so, subject to what conditions and with what effect relative to the Member State within the European Union?

\footnotetext{
${ }^{60}$ As can be seen from the example with the Marrakesh Treaty to facilitate access to published works for persons who are blind, visually impaired or otherwise print disabled (2013) where the court found sufficient competence stemming from the EU alone to conclude the contested treaty without the need for further joint ratification taking place in the Member States, Opinion 3/15, Marrakesh Treaty, EU:C:2017:114.

61 Opinion procedure 2/15, Opinion of Advocate General Sharpston, EU:C:2016:992, para 567.

${ }^{6}$ See eg Eleftheria Neframi (2010) 'The duty of loyalty: Rethinking its scope through its application in the field of EU external relations' CMLR 47(2), 323-359.

${ }^{63}$ Eugénia Da Conceição-Heldt (2014) 'When speaking with a single voice isn’t enough: Bargaining power (a)symmetry and EU external effectiveness in global trade governance' JEPP 21(7), 980-995.

64 The Agreement entered into force in February 2019, http://ec.europa.eu/trade/policy/in-focus/eu-japaneconomic-partnership-agreement/.

${ }^{65}$ Negotiations between the EU and China started in November 2013,

http://ec.europa.eu/trade/policy/countries-and-regions/countries/china/.

${ }^{66}$ Some commentators have argued that the possibility of revocation was nevertheless implied in Art 50

TEU; see eg Paul Craig (2016) 'Brexit: A drama in six acts' E.L.Rev. 41(4), 447-468; Piet Eeckhout and Eleni Frantziou (2017) 'Brexit and Article 50 TEU: A constitutionalist reading' CMLR 54(3), 695-734.

${ }^{67}$ Case C-621-18, Andy Wightman and Others $v$ Secretary of State for Exiting the European Union (UK), EU:C:2018:999. For a short case analysis, see Panos Koutrakos (2019) 'The European Court of Justice and the politics of Brexit - the Wightman judgment' E.L.Rev. 44(1), 1-2.
} 
Clarity on this issue was sought by a group of Parliamentarians ${ }^{68}$, whilst being declared a 'hypothetical and academic' question by the Secretary of State for Exiting the European Union (UK) on the grounds that the UK did not seek such revocation. ${ }^{69}$ The court of first instance accepted that reasoning and refused to make a preliminary reference in the interest of 'parliamentary sovereignty'. However, the reference was then made by the court of appeal in order to receive clarification on the number of legal options available, even if politically undesirable. ${ }^{70}$

In the main proceedings before the ECJ, the Council and the Commission acknowledged the existence of a right to revoke Article 50 TEU once triggered and before actual withdrawal of the departing Member State, however they argued that such revocation could not be a unilateral act. In particular, they raised their concerns about potential ways of abuse by the withdrawing Member State 'to the detriment of the European Union and its institutions' in an attempt to 'circumvent the rules set out in Article 50(2) and (3) TEU', essentially revoking its notification before re-applying again in order to achieve an additional extension to the two-year notification period. ${ }^{71}$ Another possible form of abuse mentioned by the institutions was the potential leverage in negotiations if the leaving Member State 'could threaten to revoke its notification and thus put pressure on the EU institutions in order to alter the terms of the agreement to its own advantage. ${ }^{72}$ The Council and the Commission therefore argued that revocation of Member States' notification to withdraw could only be allowed if the European Council unanimously consents to such a revocation.

In its judgment, the Court did not follow the Council's and the Commission's reasoning. Instead, the Court carefully analysed Article 50 TEU and the sovereign nature of the right to withdraw enshrined therein. It pointed out that despite the lack of an explicit mentioning of the possibility to revoke Article $50 \mathrm{TEU}$, any such revocation had to be understood in line with the withdrawal itself according to Article 50(1) TEU, rather than by analogy according to the procedure for extension (Article 50(3) TEU) as the Council and the Commission tried to argue. ${ }^{73}$ The Court explained that the requirement to seek approval of the European Council 'would transform a unilateral sovereign right into a conditional right subject to an approval procedure. ${ }^{74}$ As a result, a Member State could find itself in a position to being forced to leave the EU if no such approval was granted even if that Member State had changed its mind and now wished to remain within the EU.

The Court therefore held that a Member State's right to revoke Article 50 TEU has to be a unilateral right and only subject to its own national constitutional requirements. Similar as the notification itself, revocation has to be submitted in writing to the European Council, and, crucially, has to be 'unequivocal and unconditional'. Here, the Court made an attempt to mitigate the possibility of abuse by a departing Member State, trying to

\footnotetext{
${ }^{68}$ Members of the UK Parliament, the Scottish Parliament, and the European Parliament.

${ }^{69}$ Case C-621-18, Andy Wightman and Others $v$ Secretary of State for Exiting the European Union (UK), EU:C:2018:999, para 10.

70 The UK tried to appeal against the referring court's decision, however unsuccessfully.

71 Case C-621-18, Andy Wightman and Others $v$ Secretary of State for Exiting the European Union (UK), EU:C:2018:999, paras 39 and 40.

72 ibid, para 41.

73 ibid, para 60.

74 ibid, para 72 .
} 
circumvent the procedural limits of the two-year withdrawal period by re-submitting a new notification shortly after revocation: it clarified that:

the purpose of that revocation is to confirm the EU membership of the Member State concerned under terms that are unchanged as regards its status as a Member State, and that revocation brings the withdrawal procedure to an end. ${ }^{75}$

The Court thus acknowledged that there is a theoretical possibility for abuse by a Member State in order to negotiate a better deal or to obtain an extension, however this cannot set aside the sovereign nature of a Member State's decision to leave or eventually remain a member of the EU. Ultimately, any obviously abusive behaviour of a withdrawing Member State can then be met with an adequate response from the part of the EU. As has been argued by Benrath (2018), an ambiguous revocation can under certain circumstances be rejected by the European Council. In addition, the default consequence of re-notification after withdrawal would not necessarily have to result in a restart of the two-year period and thus a de-facto extension thereof, but rather should be interpreted as a resuming of the original notification period (under certain constraints) which would thus effectively limit the potential for abuse. ${ }^{76}$

The importance of this decision cannot be underestimated. And that is not only for its actual result, but even more so for the legal certainty it does provide in terms of what options are available to a withdrawing Member State after having triggered Article 50 TEU, irrespective of whether or not that state actually intends to make use of it. As such, it could be argued that this judgment has remedied one of the inherent flaws in Article 50 TEU.

\section{CONCLUDING REMARKS}

Unprecedented in its history, the UK's withdrawal from the EU has not been without challenges and continues to create legal uncertainties for all parties involved, including citizens which will be affected in their rights. The complexity of this endeavour has only become apparent peu à peu in the Brexit process, with many pitfalls and dead ends along the way.

The UK's desire to 'take back control', as often proclaimed since the UK referendum, has not (yet) materialised. Instead, if viewed from the outside, the UK seems hopelessly turning around itself without being able to present a clear strategy out of the current deadlock, let alone a feasible vision for the future. The internal quarrels have consumed much of the Government's time and resources and have occupied the judiciary at various levels. Facilitated by several unwritten rules and non-binding conventions, the legal uncertainties surrounding to the national constitutional requirements in the UK according to which the Member State in question is supposed to withdraw from the EU as prescribed in Article 50(1) TEU have largely contributed to this dilemma.

As could thus be argued, if another Member State ever were to withdraw from the EU in the future the situation would be an entirely different one. With all its internal legal

\footnotetext{
75 ibid, para 74.

${ }^{76}$ Daniel Benrath (2018) 'Bona fide and revocation of withdrawal: how Article 50 TEU handles the potential abuse of a unilateral revocation of withdrawal' E.L.Rev. 43(2), 234-248, p 245.
} 
peculiarities, the UK cannot be seen as a role model of European constitutionalism, but rather as the odd one out. Most EU countries take a less dualist approach when it comes to international law with clearly defined institutional procedures set out in their (written) constitutions and a binding distribution of competences in multi-level governance. ${ }^{77}$

The clarification on the revocation of Article 50 TEU by the ECJ has by contrast not caused any time delay on Brexit itself and allegedly not even affected the decision-making process in the UK as confirmed by the Government's repeated intention not to revoke the withdrawal process. Nevertheless, this provides useful guidance as to the options available once Article 50 TEU has been triggered, thus shifting the point of no return to the actual date of exit upon which Article 50(5) TEU applies allowing the state in question to re-join according to the procedure laid out in Article 49 TEU.

What thus remains is the challenges surrounding negotiating the withdrawal agreement as well as the (separate) future relationship between the EU and the withdrawing Member States. Again, some of the sticking points in the Brexit negotiations were UKspecific as for example the border issues between the Northern Ireland and the Republic of Ireland, however those are political questions which have to be solved by the respective representatives of each side. Legally, the involvement of the EU institutions and the remaining Member States at the different stages of the negotiations is essential to guarantee the legitimacy and proper functioning of the EU legal framework.

${ }^{77}$ See eg Germany, where even the different federated parts (Länder) have their own written constitutions. 